\title{
Potential of Small-Scale Hydropower for Electricity Generation in Sub-Saharan Africa
}

\author{
Chiyembekezo S. Kaunda, ${ }^{1}$ Cuthbert Z. Kimambo, ${ }^{1}$ and Torbjorn K. Nielsen ${ }^{2}$ \\ ${ }^{1}$ Department of Mechanical and Industrial Engineering, University of Dar es Salaam, P.O. Box 35091, Dar es Salaam, Tanzania \\ ${ }^{2}$ Department of Energy and Process Engineering, Norwegian University of Science and Technology, NO-7491 Trondheim, Norway
}

Correspondence should be addressed to Chiyembekezo S. Kaunda, kaundas@gmail.com

Received 17 May 2012; Accepted 12 June 2012

Academic Editors: B. Chen and J. Kaldellis

Copyright (C) 2012 Chiyembekezo S. Kaunda et al. This is an open access article distributed under the Creative Commons Attribution License, which permits unrestricted use, distribution, and reproduction in any medium, provided the original work is properly cited.

\begin{abstract}
The importance of renewable energy such as small hydropower for sustainable power generation in relation to its capacity to contribute towards alleviating acute shortage of rural electricity supply in the sub-Saharan African region has been discussed. A relatively comprehensive small hydropower technology review has been presented. Rural electricity supply scenario in the region has been presented and, in general, the region has very low electricity access levels coupled with various challenges. Small hydropower technology has been discussed as one of the promising decentralised power generation system for rural electricity supply in the region. Despite challenges in data acquisition, this paper has shown that the SSA has significant hydropower resources, but the level of installation is very low. Challenges hampering SHP technology development in the region have been identified and discussed, such as those concerning technology, climate change, finance, and policy. This is basically a paper where the authors consulted a wide range of literature including journals, conference proceedings, and reports as well as expert knowledge in the area. It is hoped that this paper contributes to the information base on SHP technology which is quite lacking in the region.
\end{abstract}

\section{Introduction}

Sustainable electricity supply not only supports social and economic development processes but also environmental and global climate change management and hence its importance in attainment of the Millennium Development Goals. Currently, there is an increasing electricity demand in industry, household, and services sectors in developing countries to support social-economic development activities. If this electricity is generated unsustainably and the trend is not controlled, it could lead to exacerbation of environmental and climate change management problems which the world is currently experiencing. The energy supply sector (mainly for generation of electricity), according to the Intergovernmental Panel on Climate Change (IPCC), is the largest contributor to the global human-induced greenhouse gas (GHG) emissions (responsible for global warmingmain cause of climate change); in 2004, energy supply sector contributed to around $26 \%$ of global GHG emissions, followed by forestry (17\%), agriculture (13\%), and transport
(13\%) [1]. Developing countries, especially those from subSaharan African (SSA) countries (sub-Saharan Africa as a geographical term refers to the area of the continent of Africa that lies south of the Sahara. The countries in the sub-Saharan African region are Angola, Benin, Botswana, Burkina Faso, Burundi, Cameroon, Cape Verde, Central African Republic, Chad, Comoros, Republic of the Congo, Democratic Republic of the Congo, Cote d'Ivoire, Djibouti Equatorial Guinea, Eritrea, Ethiopia, Gabon, The Gambia, Ghana, Guinea, Guinea-Bissau, Kenya, Lesotho, Liberia, Madagascar, Malawi, Mali, Mauritania, Mauritius, Mozambique, Namibia, Niger, Nigeria, Rwanda, Sao Tome and Principe, Senegal, Seychelles, Sierra Leone, South Africa South Sudan, Sudan, Swaziland, Tanzania, Togo, Uganda, Zambia, and Zimbabwe.) (except South Africa), altogether, do not contribute significant levels of GHG emission in relation to the global GHG emission levels. However, these countries are encouraged to participate in the GHG reduction initiatives because GHG reduction activities are synergistic with other national developmental programs such 
as environmental management, improvement of human health, and in general sustainable development programs. Renewable energy electricity generation is associated with very small levels of lifecycle GHG emissions which are mainly due to emissions released during manufacturing stage of their energy system components. Generation of electricity from renewable energy sources such as hydropower is, therefore, one way of responding to impacts of the current environmental degradation and climate change. Further, renewable energy resources are abundant and can be harnessed to generate the much needed electricity and mechanical power to support development programs in developing countries.

Electricity generation in SSA is characterised by acute shortages and high levels of unreliability. In most of the countries in the region, electricity generation capacities are less than $1000 \mathrm{MW}$, against huge demand for domestic, service, and industrial applications. The entire installed electricity generation capacity for all the 48 countries of sub-Saharan Africa countries excluding the Republic of South Africa is just around 30 gigawatts (GW), which is stated to be almost equal to that of Argentina [2]. A considerable portion of this installed capacity is not available for generation due to various reasons such as aging of plants, destruction of power generating systems as a result of environmental challenges such as buildup of debris (which clogs the generating system) and flooding (mainly for hydropower stations), and general plant failure as a result of limitations in plant maintenance [2]. In SSA, as it can be seen from Figure 1 that the net electricity generation by source is dominated by fossil fuel (thermal), possibly due to contributions from South Africa (which generates most of electricity from coal). Further, it can also be seen from Figure 1 that hydropower constitutes a significant portion to the net electricity generation capacity in the region. Many countries in the region, such as Angola, Cameroon, Burundi, Congo Brazzaville, Democratic Republic of Congo, Ethiopia, Ghana, Malawi, Mozambique, Namibia, Rwanda, Tanzania, Uganda, Zambia, and Zimbabwe, generate more than half of their electricity from hydroelectric power stations. Such countries include those in [3].

While hydropower is generally considered as renewable resource, large scale hydropower electricity development can result in environmental damage as well as social conflict, particularly in the case of storage-based hydropower stations. Water storage facilities (dams) in large-scale hydropower stations are known to emit GHGs, especially methane $\left(\mathrm{CH}_{4}\right)$ and carbon dioxide $\left(\mathrm{CO}_{2}\right)$. Displacement of human settlements when constructing dams and competition for water usage between power generating station owners and surrounding communities in the dam catchment area are some of the main social challenges associated with these hydropower stations. The main electricity supply effort in the region over the last decade has been on meeting electricity demand by expanding large-scale hydropower generation plants [3]. As a result, other renewable energy technologies, which may be viable sustainable power supply options to many SSA countries such as small-scale hydropower, solar and biomass resources, have been neglected.

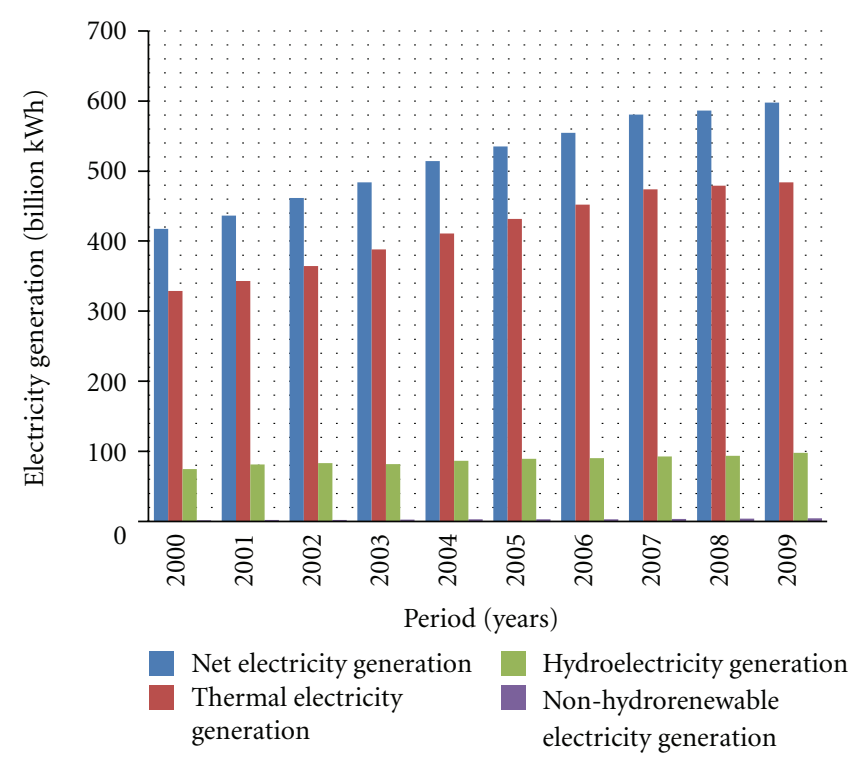

FIGURE 1: Electricity generation by source in sub-Saharan Africa from 2000 to 2009 [3].

Renewable energy technologies can be deployable in a decentralized and modular manner. This makes them suitable energy sources for small grids or off-grid solutions, thus ideal for power supply in rural off-grid regions where connection to the grid is either prohibitively expensive or technically very difficult to achieve. Renewable energy technologies are therefore arguably one of the viable solutions to the modern energy supply in SSA region where it is estimated that 66 percent of the population lives [4]. According to REN21 (a renewable energy policy network), off-grid renewable energy solutions are among the cheapest and most sustainable options for rural areas in many regions of the developing world [5].

This paper discusses the small scale hydropower in SSA region (see Figure 2) and its potential in alleviating electricity supply shortage especially in rural communities. The paper contributes towards enlarging the knowledge base on SHP technology in Africa. The lack of information on possible renewable energy technologies is one of the barriers on the uptake of renewable energy technologies for modern power supply on the continent. The next sections of the paper describe the rural electricity scenario in SSA and small scale hydropower technology, potential, application status, and challenges in the region.

\section{Sub-Saharan Africa Rural Electrification Scenario}

Sub-Saharan Africa is the only region in the world that experiences acute shortages of rural electricity supply. As can be seen from Table 1, in 2010, out of an African total population of about 590 million people without electricity, 585 million of them are found in SSA. The average rural electricity access level in SSA region is $14 \%$ as compared to 


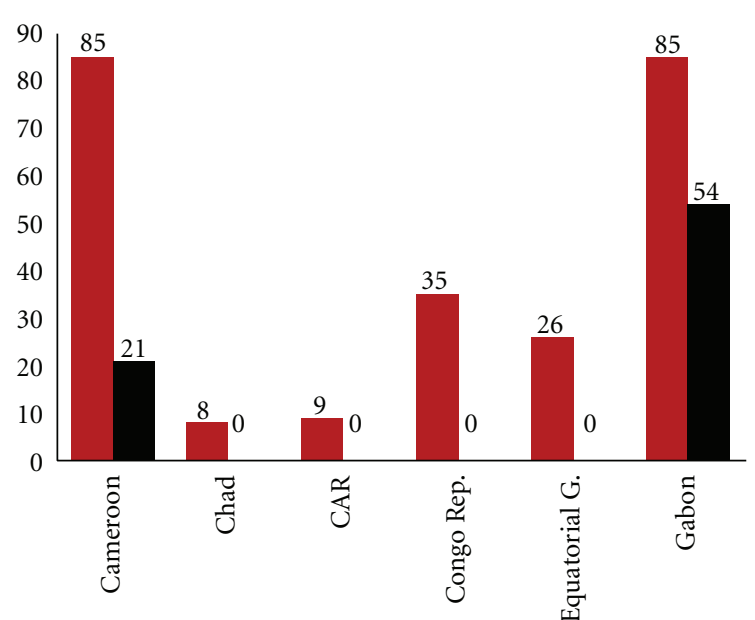

(a) Electricity access levels in Central Africa (2005)

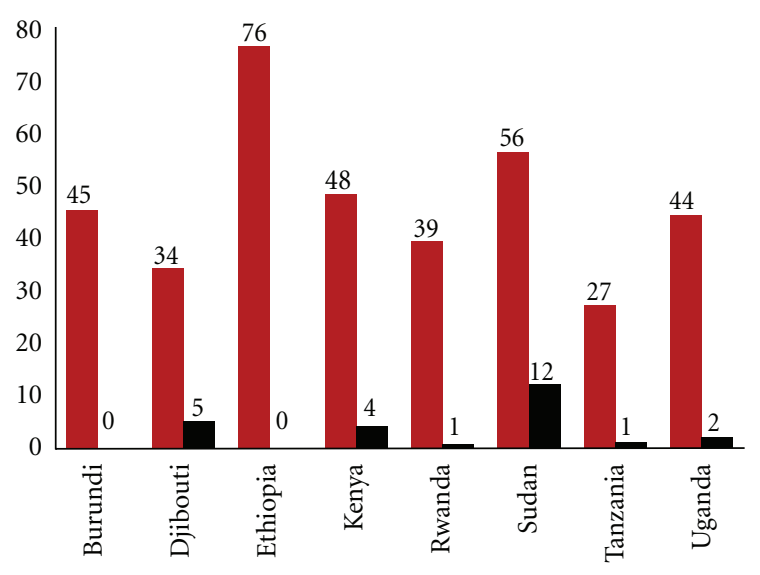

(b) Electricity access levels in East Africa (2005)

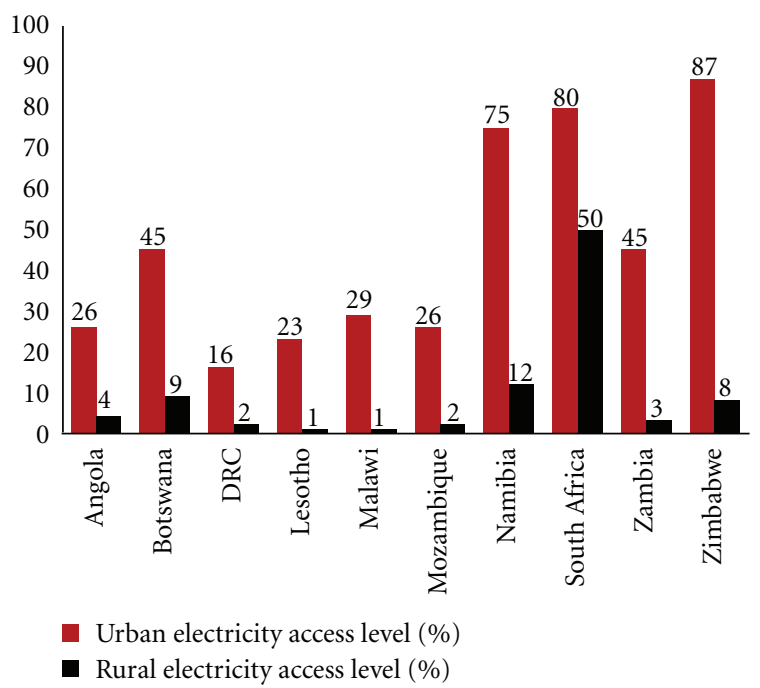

(c) Electricity access levels in Southern Africa (2005)

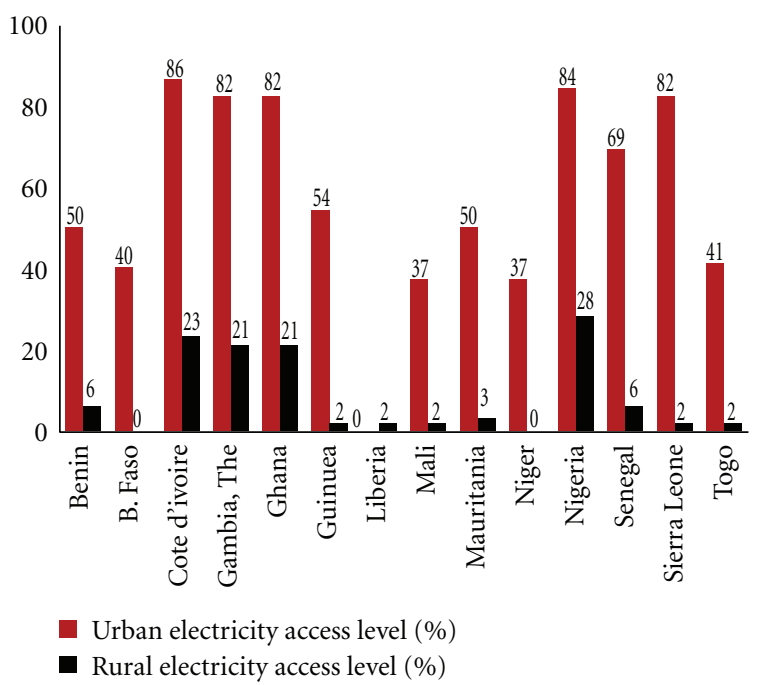

(d) Electricity access levels in West Africa (2005)

Figure 2: Urban and rural electricity access levels in sub-Saharan Africa [7].

98.4\% in North Africa, 60\% in South Asia, 74\% in Latin America, and 72\% in Middle East [6].

Electrification study by Rosnes and Vennemo in 2008 showed that levels of rural electrification vary a lot from country to country in the region. It is only Gabon (54\%) and South Africa (50\%) that have national rural electricity access levels of greater or equal to $50 \%$ (Figure 2). Many countries have levels of below $10 \%$ and some even below 2\% such as Burundi, Malawi, Uganda, United Republic of Tanzania, Mozambique, Mali, Liberia, Togo, Sierra Leone, and Eritrea [7]. Except South Africa and Gabon, all SSA countries have large difference in urban and rural electricity access levels (Figure 2). As can be seen from Figure 2, West African countries are relatively better off than the rest of the SSA subregions-Ghana (21\%), Cote d'ivoire (23\%), and Nigeria (28\%) have levels of at least $20 \%$.

In SSA region, most of the rural electrification interventions are done through extension of the national grid and are usually done by the central governments. Rural electrification through grid extension can be very expensive and technically challenging to implement as stated earlier on. Remoteness and sparseness of most of the SSA rural settlements make transmission and distribution costs of electricity expensive and sometimes prohibitive. This may explain why most governments in the region are not able to finance all the planned rural electrification programs by themselves and many of them seek assistance from development partners in this area. Most of SSA rural households cannot afford the cost associated with bringing the electricity to their load centres from the grid. Economically, most of the SSA rural electricity consumers have less disposable income to purchase electricity than their counterparts in urban areas. This is due to high poverty levels in rural communities. Further, the average price of grid electricity in the region is much higher than that in other developing regions of the world [8]. Technically, it is a challenge to transport electricity 
TABLE 1: Electricity access in 2009 regional aggregates.

\begin{tabular}{lcccc}
\hline Region & $\begin{array}{c}\text { Population without electricity } \\
\text { millions }\end{array}$ & $\begin{array}{c}\text { Electrification access } \\
(\%)\end{array}$ & $\begin{array}{c}\text { Urban electrification access } \\
(\%)\end{array}$ & $\begin{array}{c}\text { Rural electrification access } \\
(\%)\end{array}$ \\
\hline Africa & 587 & 41.8 & 68.8 & 25.0 \\
$\quad$ North Africa & 2 & 99.0 & 99.6 & 98.4 \\
Sub-Saharan Africa & $\mathbf{5 8 5}$ & $\mathbf{3 0 . 5}$ & $\mathbf{5 9 . 9}$ & $\mathbf{1 4 . 2}$ \\
Developing Asia & 675 & 81.0 & 94.0 & $\mathbf{7 3 . 2}$ \\
China and East Asia & 182 & 90.8 & 96.4 & 86.4 \\
South Asia & 493 & 68.5 & 89.5 & 59.9 \\
Latin America & 31 & 93.2 & 98.8 & $\mathbf{7 3 . 6}$ \\
Middle East & 21 & 89.0 & 98.5 & $\mathbf{7 1 . 8}$ \\
Developing countries & $\mathbf{1 , 3 1 4}$ & $\mathbf{7 4 . 7}$ & $\mathbf{9 0 . 6}$ & $\mathbf{6 3 . 2}$ \\
The world & $\mathbf{1 , 3 1 7}$ & $\mathbf{8 0 . 5}$ & $\mathbf{9 3 . 7}$ & $\mathbf{6 8 . 0}$ \\
\hline
\end{tabular}

Source: International Energy Agency [6].

through long distances because of transmission losses and technical difficulties in maintaining such a long grid network system. Already in most of the SSA countries, the system transmission and distribution losses are above the normal acceptable values with an average of $25 \%$ of the electricity generating capacity [9] such that if such a grid network is extended to supply electricity in most of the rural areas, the electricity transmission efficiency of the network would drastically reduce, resulting in economic losses to the power utility company.

Rural electrification using modular and stand-alone renewable energy systems are at infancy stage in the region. Most of the renewable energy rural electrification projects and programmes that have so far been implemented in SSA are those dealing with solar photovoltaic (PV) installations (most of them financed by international development agencies and central governments). The majority of these solar PV installations have been those of institutional type (rural health centres, police units, and schools) mainly for lighting, communication, and few for water pumping. Household solar PV installations are not many-the majority of them being the systems installed by the projects for technology demonstration purposes and those installed by worthy people in urban areas for their parents and relatives in the villages. At household level, the investment costs of solar PV systems are very high for the majority of typical rural SSA households to afford so as to meet their energy requirements. Further, solar PVs do not provide households (even institutions) with many of their required energy services especially for thermal and mechanical power applications [10]. Furthermore, solar PV technology is expensive to maintain, it requires purchase of supporting systems such as invertors, batteries, and special low-wattage appliances; as such rural electrification projects especially those using solar home systems (SHP) have been known to benefit only a few rich households in rural communities in the region because the poor households may not use the technology despite having the installed system [11]. The limitation of the majority of rural households in using the installed renewable energy electricity may also apply to other renewable energy sources, not only to solar PV as discussed. Therefore, in most SSA countries, renewable energy electricity may be used optimally if it is supplied to institutions, to a community (or settlement), and if it supports income generating activities, unlike targeting individual households. This calls for a need for a robust stand-alone energy system that can be installed to supply electricity to satisfy the diverse range of energy requirements so as to stimulate and support social-economic activities of the rural communities. Section 3 looks at small hydropower as one of renewable energy technologies that is robust enough to be used for institutional and income generating applications in a stand-alone mode.

\section{Small Hydropower}

Small hydropower (SHP) system is one of the renewable energy technologies for generating electricity and mechanical power. SHP system is categorized as being "small" depending on the capacity of the installed electricity. There is no international agreement on the limit of "small", but most European and other countries accept $10 \mathrm{MW}$ as the upper limit [12]. Within the SHP category, the systems are further categorized into pico, micro, mini, and small systems. Most of the countries and organizations recognize pico as a system that generates less than $10 \mathrm{~kW}$, micro (more than $10 \mathrm{~kW}$ but less than $100 \mathrm{~kW}$ ), mini (more than $100 \mathrm{~kW}$ but less than $1 \mathrm{MW}$ ), and small (above $1 \mathrm{MW}$ but less than $10 \mathrm{MW}$ ). With such type of installed capacities, SHP is more robust than a PV system. SHP installed systems therefore are better placed to support diverse energy requirements for institutional, community, and small scale industries in remote locations, than either solar PV and wind power. The SHP can be of a reservoir or run-of-river type: run-of-river types have no water storage for power generation, but, instead, water for power generation is diverted from the main river via a weir. For small capacities of SHP, run-of-river types are ideal because, with absence of a reservoir, investment cost per $\mathrm{kW}$ of installed electricity is reduced (for small SHP systems, the main emphasis is on reducing investment cost). A typical run-of-river SHP system for electricity generation is composed of the following basic components: water 
intake structure (e.g., weir and settling tank), penstock, turbine, mechanical power transmission system to generator, generator, electricity transmission system to load centres, and control system. Some of these basic components are shown in Figure 3.

SHP is a site-specific technology and as such not all locations on the river flow course are ideal for SHP development except those that have considerable sizes of head such as sloping sections of the river and natural falls. This shows that most of the potential sites for SHP are found in mountainous areas with perennial rivers. Not only does the site dictate the SHP system size (as well as its type) but also the level of complexity of SHP system civil works and thus the investment cost per $\mathrm{kW}$ of installed power. The system investment cost also depends on local economics and government taxes that are imposed on system components as well as on the labour services. The investment cost of a typically system ranges from US $\$ 1,000$ to US $\$ 20,000$ per $\mathrm{kW}$ of installed electricity [14]. Maintenance costs of SHP plants are relatively small in comparison to other technologies such as diesel generators. SHP is a long-lasting and robust technology - the life span of a well-installed SHP systems can be as long as 50 years or more without major new investments on parts, replacements (the average life considered for investment purposes is about 30 years) [15].

As an electricity generation technology, SHP is a very efficient energy technology because electricity is generated directly from the shaftpower. SHP system for power supply is a well-matured technology as the case with solar PV and wind energy systems. SHP technology is already being applied as one of the energy interventions in most of the Asian countries such as India, Peru, and China $[14,16,17]$. In SSA region, the technology is not applied widely despite the region stated to have enormous SHP resources [18]. The SHP technology was first introduced in the region by missionaries and tea planters and its development is currently championed by international development agencies, most of which are not research-based institutions, as a result, information about SHP in SSA is limited in academic arena. The technology awareness seems to have penetrated in most of SSA countries as evidenced by the inclusion of SHP energy systems in most of the rural electrification master plans, for example, in Malawi, Tanzania, and Mozambique. There is an opportunity for further popularisation of the technology because most of the SSA countries have liberalized their energy sectors, allowing for independent (private) power generation and selling it to the national power utilities through independent power purchase agreements. In fact, private sectors in Kenya and Rwanda have started venturing into SHP generation business [18].

In general, SHP schemes have relatively low lifecycle investment costs per $\mathrm{kW}$ of installed power and through their modular nature, it is possible to size the system to meet specific power demand according to potential of the site and the available finances. It is also possible to integrate SHP system with other small scale renewable energy systems such as solar photovoltaic, wind, and biomass power systems to optimise harnessing of the available local renewable energy resources for power generation. SHP systems especially

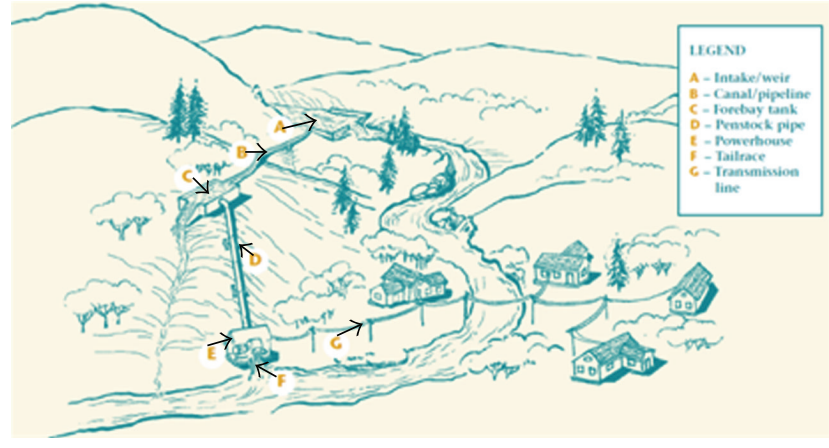

FIGURE 3: Basic components and arrangement of run-of-river small scale hydropower system [13].

pico- and micro-hydropower systems offer potential for SSA countries to generate electricity, as the system can be designed and installed using local resources: materials and labour. This creates job opportunities and ability to use technology to advance standard of living in the region.

Basically, the power exploited from hydropower at a particular site is proportional to the product of flow rate and head as given in the following:

$$
P=\eta_{o} \rho g Q H,
$$

where $\rho$ is a density, $g\left(\mathrm{~m} / \mathrm{s}^{2}\right)$ is the acceleration due to gravity, $Q\left(\mathrm{~m}^{3} / \mathrm{s}\right)$ is the flow rate, and $H(\mathrm{~m})$ is the net head available at the inlet to the turbine and $\eta_{0}$ is the overall energy conversion efficiency (hydraulic to shaftpower). The values for overall efficiencies are higher in large-scale hydropower than SHP projects because, for large scale, the systems are designed with relatively high levels of precision and accuracy. The overall efficiency (hydraulic power to electricity) for SHP electricity generation system is lower (less than $80 \%$ ) than for mechanical power supply system because of generator losses in the former [15]. The energy potential at a site is fixed by flow rate and head (see (1)); thus, there is a limit at which hydropower can be exploited at a particular site and once this is reached, further power expansion is not possible.

Before an SHP system is installed on a site, it is important to determine the power that will be harnessed from the site as given by (1). The information on flow rate and head at the site as well as other site conditions are important in the design of the whole SHP system. It is important to first undertake a desk study hydropower resource assessment using hydrological and topographical graphs/maps as well as geographic information system (GIS) and flow duration curve before undertaking a comprehensive feasibility study of the site. The desk study provides a variety of site information important such as slope, power canal length, availability of access roads, distance to load centres, area of the catchment, head available for power generation, flow rate, and firm power to be generated. The design flow rate is obtained from the annual flow duration curve of the river at the site and head is determined from the topographical map (as well as GIS). Determination of design flow rate and other hydrological characteristics is quite a challenge task 
unlike head. In SSA, most of the prospective sites for SHP projects are either ungauged or have insignificant data for design analyses. In this case, estimation of the hydrological characteristics especially flow duration curve is done using models. These models estimate the flow duration curve at the ungauged site from gauged sites of similar catchment characteristics. The results of the desk study are important for decision making, to continue with the project or not. If it is decided from the desk study to continue with the project, then it is important to undertake comprehensive feasibility studies by visiting the site and taking actual measurements of head and flow rate.

The shape of the flow duration curve describes the suitability of the site for SHP production. A very steep curve shows abrupt change in amount of discharge for a relatively short period of time-signalling that the site is prone to floods (unsuitable). The design of SHP system can be based on three design flow rates: (i) the plant is designed based on minimum potential power that is obtained from minimum annual flow rate. Minimum annual flow rate is the flow rate that is available at least at all the times in the year, written as $\mathrm{Q}_{100}$. The SHP plant design based on the minimum annual flow rate gives the plant a theoretical capacity factor of $100 \%$. (ii) the plant is designed based on small potential power when the design flow rate that is equivalent to the $95 \%$ of the time flow is exceeded (or flow that is available for $95 \%$ of the time in a year, $Q_{95}$ ) giving a theoretical plant capacity factor of 95\%; (iii) finally the plant can be designed based on average potential power when the design flow rate is equivalent to $60 \%$ of the time flow is exceeded (or flow is available for $60 \%$ of the time in a year, $\mathrm{Q}_{60}$ ) giving a theoretical plant capacity factor of $50 \%$ [19]. For very small systems, such as pico-hydropower plants (less than $10 \mathrm{~kW})$, some of the routine design procedures such using flow duration curve are not normally followed [20].

From Figure 3, one of the most important components of the SHP system is a turbine; in fact some of the SHP systems are named after the type of the turbine. The turbine is a mechanical device that converts hydraulic power in the water into mechanical power-known as shaft power and is usually placed in the powerhouse. This shaft power is converted into electricity by the generator; thus, the turbine determines the electricity capacity of the SHP installation. The most common types of turbines for SHP application are Francis, Kaplan, Pelton Wheel, Crossflow, and Centrifugal pumps operated in turbine mode. Different turbine types have different efficiency profiles with respect to discharge as can be seen in Figure 4. As can be seen from the figure, the hydraulic performance of the Propeller turbines is more sensitive to flow variations than Francis, Kaplan, Pelton, and Crossflow turbines. Pelton Turbine is not only one of the most efficient turbines (around 90\%) but it can also sustain the optimum efficiency for a variable range of flows. Crossflow turbine has relatively inferior efficiency levels (around 80\%), but the turbine can sustain optimum efficiency levels for a range of flows [21]. Crossflow turbines are widely used in developing countries, such as Ethiopia, for development of MHP systems [22]. Crossflow turbine runners are simple to manufacture because the blades can be made from standard steel pipes'

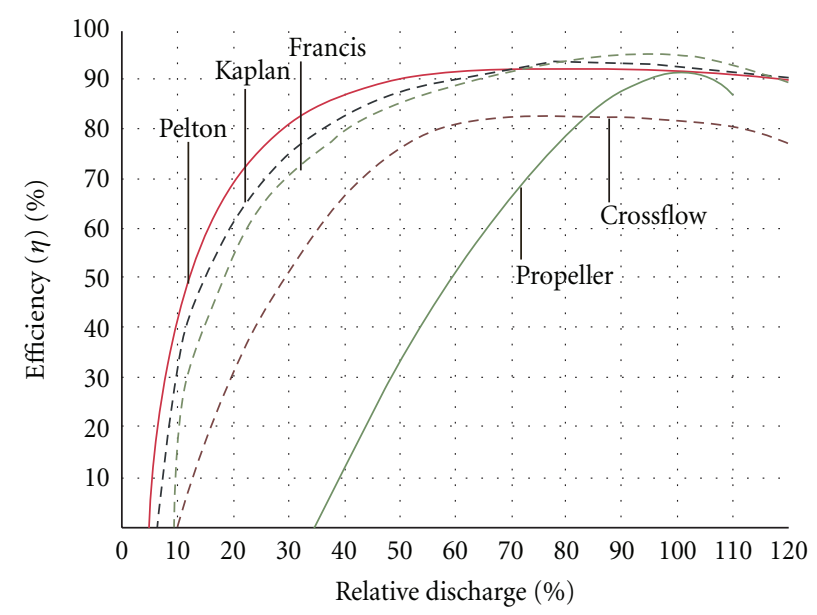

Figure 4: Typical efficiency curves for different types of hydropower turbines [21].

cuts and, as such, they are relatively of low cost per $\mathrm{kW}$ of installed electricity than others.

Design charts have been developed by turbine manufacturers to help in selecting the appropriate turbine for the development of SHP site according to the head and power requirements. An example is the turbine application range chart shown in Figure 5. As can be seen from the chart, Kaplan and Propeller turbines can effectively be applied in low and medium head sites with power requirements of more than $1 \mathrm{~kW}$, Crossflow turbines can be applied in all head ranges with power requirements of more than $5 \mathrm{~kW}$, and Pelton turbines can be applied only for high head with power requirements of more than $50 \mathrm{~kW}$. This chart agrees with the rule of thumb that Pelton turbine is for high head while Kaplan and Propeller turbines are for low head applications.

SHP technology is continuously undergoing improvement both in areas of technical performance and investment cost reduction. Availability of cheap PVC pipes which are commonly used as penstocks and use of cheap electronic load controllers (ELCs) to control electricity generation in place of expensive mechanical governors make the investment cost of an SHP system per $\mathrm{kW}$ of installed electricity compare favourably with most of the renewable energy systems currently $[24,25]$. Further, use of relatively cheap synchronous motors as generators and development of relatively cheap Crossflow turbines have helped to reduce the unit power investment cost of the system further. In developing countries such as those in the sub-Saharan African region, the local capacity to manufacture electromechanical (generating) component (turbines and generators) is important when it comes to reducing investment cost because exported turbines and generators tend to be relatively expensive for an SHP project. The other advantage for local development of SHP systems in SSA region is that manual labour to work on excavations and to transport construction materials as well as system components to the site is readily available.

Small hydropower plants are long-term investments, and since they are installed in locations where the operators and consumers are relatively less informed technically, it is 


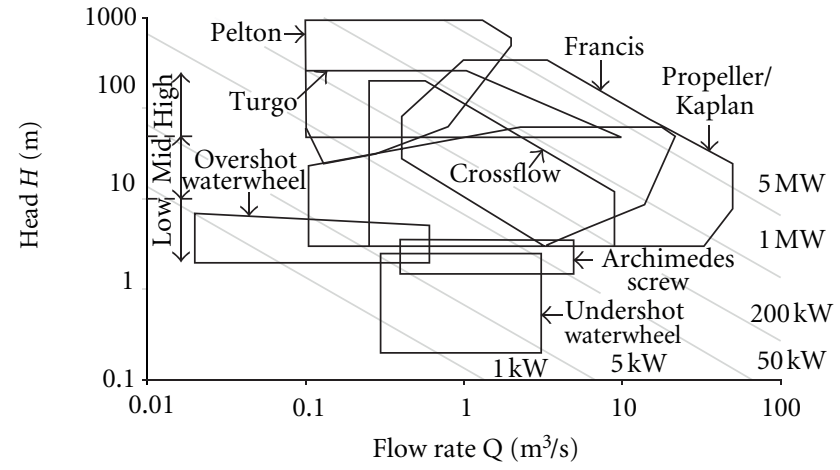

FIgURE 5: Turbine application range chart [23].

important to design the systems so that they are most of the times operated in unattended mode and also that safety issues are incorporated to protect both the user and the plant. Electromechanical components such as turbine, generators, controllers, and switch board need to be secured in a power house that is specifically constructed for such a purpose. In the power house, rotating components such as shafts and belts should be guided properly to prevent accidents. Civil components such as intakes, power canals, and penstocks need to be secured properly. For PVC pipe penstocks, it is recommended to bury them so as to protect them against being trampled on by livestock (for example). It is also recommended to bury PVC pipe penstocks so as to minimise their rate of thermal degradation as a result of heat from solar radiation. For a well-installed SHP system, the lifecycle of the system can be more than 50 years (as already stated), and to achieve this, it is important to develop (at country level) installation and safety procedures to ensure the structural integrity of the installation and its optimal performance as well as safety. For SHP electricity system supplying electricity to a community via minigrid, it is recommended that national standards/procedures regarding decentralised electricity installation and safety should be applied. In the absence of such standards/procedures, development of SHP can face a stumbling block from negative publicity emanating from poor installations which are major causes of system malfunctioning and accidents.

\section{Potential of Small Hydropower in SSA}

The current technology of harnessing SHP uses potential energy in water as a result of presence of head in the river to drive the water turbine, as stated earlier on. Basing on this current technology, the potential of generating electricity and mechanical power from small scale hydrosystems is qualitatively stated to be enormous in many countries in SSA Africa [4] due to its geographical features: presence of perennial rivers and mountainous locations especially in central, eastern, and some southern parts of Africa. It should be pointed out that most countries do not have a complete up-to-date national inventory of the potential sites for the installation of the SHP systems; in terms of head, flow rate, firm power output, and unit power investment cost. This is one of the challenges for the development of SHP in SSA and is briefly discussed in Section 6. Most of the practical data on SHP is obtained from SHP projects developers who usually conduct their own SHP energy resource assessment studies at the potential sites for development of their systems. Currently, many national power utility companies in conjunction with governments' departments of energy have started the SHP resource mapping exercises in the region, for example the Tanzania Electricity Supply Commission in Tanzania [26], Department of Energy Affairs in Malawi [27], and the Energy Foundation of Ghana [28].

Bearing in mind the likelihood that the current SHP may not give up-to-date accurate inventory of the potentials SHP in the region plus the fact that other potential SHP sites are yet to be identified and assessed, this paper tries to give a picture of the recorded SHP potential in some selected SSA countries as follows.

(i) Malawi has an SHP potential of $7.35 \mathrm{MW}$ from the identified 22 sites in [29], and in 2002, JICA feasibility studies identified a further $345 \mathrm{~kW}$ microhydropotential which has been included in the rural electrification for the country [27]. The SHP potential in Malawi is mostly located in the Northern Region of the country bordering with Tanzania and areas surrounding Mulanje Mountain in the Southern Region;

(ii) Tanzania is reported to have an SHP potential of 185 MW from the 85 identified sites: the resource assessment was conducted by TANESCO with financial help from the Tanzanian Ministry of Energy and Mines and technical help from IC-SHP of China [26], and TANESCO is reported to continue with SHP resource identification, assessment, and updating the information previous identified and assessed sites. Most of the sites are located in the southern part of the country bordering with Malawi, Zambia, and Mozambique. So far, from the inventory of SHP in Tanzania, only 5 sites have been appraised and are included in the Rural Electrification Master Plan [26];

(iii) Uganda has an identified SHP potential of more than 50 sites with a total potential of about $210 \mathrm{MW}$. Further, the country in 2009, registered at least 13 licenced SHP developers with a projected installed electricity capacity of about $85 \mathrm{MW}$ plus a planned installed capacity of $23 \mathrm{MW}$ from other unregistered projects. Installation works in 10 of the 13 registered projects were not yet completed by 2009 [30].

(iv) Mozambique is stated to have over 60 identified potential sites with a potential of over $1000 \mathrm{MW}$ of electricity mostly in central and eastern regions [31];

(v) In 2009, Rwanda is reported to have a potential of 333 potential micro-hydropower sites and that 25 of them were being developed under the financial and technical assistance from Belgian Technical Cooperation (5 micro-hydropower plants of 5,15 MW total 
capacity) Dutch-German Partnership, Energizing Development (6 sites currently being developed of 1.6 MW capacity), Government of Rwanda ( 8 microhydroplants of $6.35 \mathrm{MW}$ capacity) and UNIDO (4 micro-hydrosites). These small scale hydropower systems will generate electricity that will be integrated into the national grid and some will be used for offgrid application [32];

(vi) In Ghana, in 2010, it was reported that a total of 21 mini-hydropower sites had been identified and assessed in the country with potential electricity output ranging from $4 \mathrm{~kW}$ to $325 \mathrm{~kW}$ [33];

(vii) Kenya is stated to have an estimated SHP potential of about $3000 \mathrm{MW}$ in 2011 [34].

As a whole, the potential for SHP (pico, micro, and mini) in Africa is estimated to be above $10 \mathrm{GW}$ and only about $0.5 \%$ has been developed [35]. Again, technically, it is possible to divert small portion of the flow from the big river for power generation; this means that even largescale hydropower sites could as well be potential sites for SHP development. Thus, in general, SSA has significant SHP potential which if harnessed can improve access and supply of electricity to rural off-grid communities.

\section{Installation Status of Small Hydropower in SSA}

In general, there is scarcity of data on the actual number and characteristics of installed SHP systems in SSA, some of the data not available in a form suitable for quantitative analysis. This paper, therefore, attempts to provide a platform for the inventory of SHP in the region. As it is clear that not all installed systems have been captured in the paper, the paper just gives a picture on the level of installation in the region, and based on these numbers, subsequent refinement on the inventory can be made. As stated earlier on, SHP technology was introduced in most of SSA countries by early missionaries and tea planters for the sole purpose of providing power to their mission bases and plantations, such as in Malawi [36], Tanzania [37], and Kenya [38]. Some of these early systems are still functional as of today. The SHP installation level (in terms of installed electricity capacity) in some selected SSA countries is given as follows.

(i) In Kenya, SHP contributes $15 \mathrm{MW}$ into $745 \mathrm{MW}$ hydropower grid-based electricity installed capacity and the SHP off-grid installation capacity is $31 \mathrm{MW}$ [34]. With the liberalization of Kenyan energy sector and the introduction of feed-in-tariff, independent power producers are investing in SHP, for example, in 2011,19 SHP proposals amounting to $111 \mathrm{MW}$ under the feed-in-tariff were submitted and 16 of them (with a total capacity of $81 \mathrm{MW}$ ) were accepted [34].

(ii) Ethiopia has a reasonably high installed capacity of $80 \mathrm{MW}$ of SHP electric plants [35]. The installed offgrid SHP systems are used for supplying electricity for domestic application in rural households, rural microenterprises, institutions (such as missions and schools), and tea factories.

(iii) SHP in Rwanda, in 2009, contributed 6.5 MW into the generation capacity of about $43 \mathrm{MW}$ from hydropower [32]. The total electricity generation capacity of Rwanda, in 2009, was about $72 \mathrm{MW}$ [39]. Rwanda, as with Kenya, is one of the countries where the potential market for microhydro off-grid electricity is high. According to the market research done by Meier and Fischer [40], there is strong demand for pico- and micro-hydropower systems in the country in the offices, schools, health centres, local small business, cottage industries, and some local village communities. The research discovered that the willingness to pay for the electricity on the part of the beneficiaries was high. In fact, the research discovered that there were already 7 SHP site developers in the private sector operating in the country involving all steps of developing an SHP station including manufacturing of electromechanical equipment of the systems. The private sector has realized installation of about 30 pico-hydroplants in Rwanda by 2011. Thus, Rwanda is a good case study for the promotion of SHP technology through rural electrification private sector involvement. SHP electricity is supplied to the local communities through a minigrid and every household pays a monthly tariff ranging from 2.5 to 5 US\$ depending on usage.

(iv) Although a lot of effort and resources have been expended on numerous resource assessment studies, not a single mini-hydroplant has been developed in Ghana by 2002 [41].

(v) In Malawi, despite the proven studies on potential SHP sites for rural electrification (off-grid mode) and grid-fed electricity generation, only Wovwe (4.5 MW installed capacity) has been achieved for grid-based electricity [42]. However, from a research conducted by Kaunda [36], there are a few installed micro-hydropower systems for rural electrification in Malawi by missionaries, tea estates, and lately by development partners such as Practical Action, contributing about 1.3 MW of off-grid electricity supply.

(vi) In Uganda, by 2009, a total of about $17 \mathrm{MW}$ SHP electricity capacity was installed and integrated into the national grid [30].

(vii) Tanzania is one of the countries where there is relatively large number of micro- and mini-hydro installations, some of which have been installed by TANESCO, missions, and NGOs. From the research analysis done by the lead author of this paper, the installed capacity from 29 identified SHP systems in different parts of the country is $5.4 \mathrm{MW}$.

At the moment, several initiatives are in progress to assist developing small hydropower in some SSA countries through international development agencies such as 
UN-based agencies like United Nations Development Program (UNDP), United Nations Environment Programme (UNEP), and United Nations Industrial Development Organisation (UNIDO). Other international agencies such as Japan International Cooperation Agency (JICA) and Practical Action have also been active in promoting SHP technology in SSA countries. These agencies have been involved in supporting programmes to remove barriers to harnessing of power from SHP potential and technology dissemination. One example of such interventions is the establishment of regional (ECOWAS) SHP training and support Centre Abuja, Nigeria by UNIDO in 2006. The Centre provides trainings on SHP feasibility study, analysis, design, development, and implementation of SHP systems in the Economic Community of West African States (ECOWAS) region [43]. Apart from Nigeria, UNIDO has been very active in installation of demonstration SHP systems in SSA countries such as Tanzania, Rwanda, Mali, and Kenya [44]. Other agencies have also been assisting countries to undertake resource assessment studies such as JICA in Malawi [27]. The German Organisation for Technical Cooperation (GTZ) has also been active in supporting installation of community-based micro-hydropower systems as well as SHP resource assessment in Uganda [30]. Also bilateral donors and nongovernmental organisations (NGOs) have embraced SHP as a viable means to provide modern energy to rural areas, such as the Oikos East Africa (with funding from European Union) in Tanzania [45], Practical Action in Southern Africa (Malawi, Mozambique and Zimbabwe-as discussed in the subsequent paragraphs) with more funding contributed by the European Union as well.

The result of this intervention is that a number of SSA countries, either through their departments of energy or national power utility companies have established rural electrification master plans that include development of SHP; for example, the Malawi rural electrification master plan includes 11 sites with a power potential of $345 \mathrm{~kW}$ [27]; the Tanzania Rural Electrification Master Plan include development of 5 SHP systems [26]; the Uganda government has developed an Indicative Rural Electrification Master Plan (IREMP) which includes development of the available SHP sites [30].

On regional basis, the following are some of the donor funded projects specifically on promoting SHP technology for rural electrification in SSA.

The UNEP is implementing a Global Environment Facility (GEF) funded project that looks at the possibilities of applying SHP technology in tea estates to generate electricity for use in tea factories and the excess electricity for rural electrification of the nearby communities in the Eastern Africa region plus Malawi and Mozambique [46]. The Project further looks at reducing GHG emissions through promotion of SHP technology. Under this project, a collaboration of the East African Tea Trade Association (EATTA), UNEP, the African Development Bank, and the GEF has set up a facility to accelerate the uptake of SHP in the region. The project is reported to have been strongly accepted by the tea estates owners because it provides a solution to the limited and unreliable power supply from their national electricity grids. The Project aims to establish 6 SHP demonstration projects in 4 of the EATTA member countries [47]. For the case of Malawi, in 2009, the project conducted feasibility study on two sites on the upper Ruo River and one site on the Lujeri River to determine the potential to develop and upgrade the generating capacity of an existing SHP system at the Lujeri Tea Estate in Mulanje District, southern part of the country. The study concluded that SHP development and expansion at the sites was technically and financially viable as well as environmentally acceptable. The project was not implemented because the Lujeri Tea Owners did not want to lose production during the period (about 18 months) the existing SHP plant was to be shutdown as it undergoes upgrading. However, the project has laid down the necessary design data for any organisation/company that would want to install the SHP on the sites in future [48]. According to the Project Mid-Term Evaluation Report, by 2010 the 6 SHP installations in 4 countries (Kenya, Rwanda, Uganda, and Tanzania) were not yet completed but were in good progress [49].

In West Africa, UNDP is implementing a UNDPGEF Regional that looks at promoting micro-hydropower technology as a decentralised power system for off-grid rural electrification. The project is taking place in 10 ECOWAS countries (Cameroon, Mali, Central African Republic, Democratic Republic of Congo, Gabon, Congo/Brazzaville, Rwanda, Equatorial Guinea, Togo, and Benin) plus Burundi. It is scheduled to be completed by 2015 , and for each of these 11 participating countries, the project will strengthen the institutional, regulatory, and operational capacities of key agencies to provide decentralised microhydro-based electricity access to remote rural areas. The project will further install 36 demonstration micro-hydropower plants for rural electrification in the 11 countries using different technology models. The lessons learned at national level will be shared amongst the participating countries in order to effectively develop viable delivery models [50].

Practical Action, a British-based nongovernmental organisation, is implementing a regional micro-hydropower project in Malawi, Mozambique, and Zimbabwe under the header of the EU funded project "Catalysing Modern Energy Service Delivery to Marginal Communities in Southern Africa." The project seeks to promote the use of renewable energy through creating micro-hydropower technology expertise in rural communities by equipping the community members with technical skills in design, fabrication, installation, maintenance, and operation as well as the ability to organise and control the project. On the regional level, the project aims to develop a regional pool of local micro-hydropower expertise in Malawi, Zimbabwe and Mozambique thereby transforming them into centres of excellence in microhydropower technology with capacity to provide technical and social support for microhydro project design, manufacturing, quality standards, maintenance, and operation of system. The project will install 15 demonstration microhydropower schemes to be implemented through local partners (in Malawi and Mozambique only) in the three countries concerned as follows: 
(i) Malawi-2 schemes in Likhubula and Thuchila rivers implemented by Mulanje Mountain Conservation Trust (MMCT) in partnership with Mulanje Renewable Energy Agency (MuREA);

(ii) Mozambique-9 schemes in Mukudu, Chadzuka and Chuwa in Machipanda implemented by Kwayedza Simukai Manica (KSM);

(iii) Zimbabwe-4 schemes in Nyafaru, Nyamarimbira and Chidokori implemented by Practical Action.

The project is in the middle phase of its implementation and installation of three demonstration microhydropower systems in each of the three countries has been completed. These demonstration systems are Bondo Microhydropower scheme in Mulanje District, Malawi; Chipendeke Microhydropower scheme in Mutare District, Zimbabwe; Ndiriri Microhydropower scheme in Manica District, Mozambique $[47,51,52]$.

Despite the challenge of having scattered information on SHP installations, it can be seen that the level of installations is very much low when compared to the potential available. Section 6 discusses the challenges being faced to develop SHP technology in the SSA region.

\section{Challenges: SHP Development in SSA}

In general, one of the major challenges hampering SHP development in the region concerns technology limitations on the part of local human resource to implement the technology in the following areas.

(i) Conduct feasibility studies on the identified sites to provide required data, both technical and economic type of data, to inform SHP designers. Lack of accurate design data in most of the identified SHP potential sites is one of the reasons for the installation of malfunctioning systems in the region. Very few governments have SHP inventories of potential sites with only names and their locations as well as estimations of head and flow rates: many inventories are not exhaustive and are outdated. Some of the governments rely on feasibility study results that are conducted by international development agencies (most of them use expatriates for the job) to update their inventories, but clearly it may not be possible for these agencies to characterise all the identified SHP in the country, unless it is their main project and, further, some of the agencies may not be willing to share data. It is possible to take advantage of opportunities for short-term trainings as well as partnerships with SHP regional (as well as country) centres of excellence such as that of Abuja instituted by UNIDO and SHP program in Rwanda and Kenya to improve the local capacity to conduct feasibility studies. Furthermore, the governments and national power utility companies should make a deliberate effort to have up-to-date databases of SHP sites and train their technical staff to conduct the feasibility studies. Governments are usually the official custodians of public data and an up to date SHP database is one of the prerequisites for the establishment of a vibrant private sector driven SHP development in the region.

(ii) Plan, design, and operate the SHP system. Many governments, as a result of SHP technology awareness campaigns, have incorporated SHP in rural electrification plans (as discussed already); the very low levels of government sponsored installations are argued to be partly due to limited human capacity in this area [53]. Training of local human resource is also necessary in this regard. However, there has been a lot of technical people especially from government departments and national power utilities attending short-term and tailor-made trainings in SHP, but the technology is still not wide spread. This is argued to be due to centralised administrative framework which tends to localise the acquired knowledge, experience, and skills in governments' ministries and national power companies. This has resulted in the absence of qualified third-party operators in rural communities to implement SHP technology, as with the case in Tanzania [54].

(iii) Manufacture the system components such as turbine parts and generators. Most of the turbines and generators are imported and are relatively expensive due to some added costs of transportation and taxes. Thus, with lack of capacity in manufacturing system components, not only does the investment cost per $\mathrm{kW}$ increase but also the local availability of spare parts is limited resulting in increased number of notfunctioning installed systems merely due to unavailability of the required parts. Further, the imported spare parts are prohibitively expensive to purchase for a small-scale power production system. This is one of the serious barriers to the development of SHP in SSA region. Furthermore, the extent to which damaged off-grid power systems components can be repaired locally using locally sourced materials and human resource is stated to be one of the important issues in implementing sustainable power systems [55]. If the technology is not supported by skilled technical expertise, it is prone to failure and the faulty systems can remain in their state of disrepair for long period of time. The availability of local knowledge and support networks for the SHP technology is specifically important because the systems are typically installed in remote rural areas where it is crucial to maintain systems in good working order over their useful lifetime. The local capacity and support networks may include central government institutions (such as the departments of energy), national power utility companies, local government authorities, and beneficiary institutions/household representatives.

(iv) There is limited SHP technology innovation in most of the SSA countries as compared to the developing 
countries of Asia such as Peru. This is due to limitations in research and training in SHP technology in higher learning institutions and SHP centres of excellence both at regional and national level (as discussed earlier on). The existence of government funded research and technology development centres in most of SSA countries can offer the opportunity to introduce SHP technology innovation centres in the region.

The other challenge facing development of SHP in SSA is the civil strife in some of the countries resulting into military activities. Clearly, this poses as a barrier to the development of small hydropower technology in those countries. During military activities most of the infrastructures that support essential services are targeted for vandalism and looting as being part of the weapons of war. Since small scale hydropower systems are quite robust technology both in terms of plant size and installed power capacity, and many are installed in remote rural areas supporting essential services, they may be easy targets. In some cases, tribal/community clashes concerning ownership of water resources have rendered the utilisation of water for other purposes such as for power generation limited or stopped at all. In such environments, the future of SHP infrastructural projects looks not promising. Therefore, it is advisable that during planning stage, there is need to study the socialpolitical environment in the installation areas and to develop measures on how to manage SHP installations in such politically volatile environments.

Most of the sub-Saharan African countries rely on hydropower for electricity generation [56] as pointed out earlier, and since hydropower depends on the runoff [57], the region's power sector including SHP systems is therefore vulnerable to water scarcity as a result of climate change related occurrences such as decreased levels of precipitation, increased levels of evaporation and droughts $[58,59]$. Some researchers, such as Klunne [60], propose that since SHP systems are run-of-river (especially micro and pico systems and that small volumes of water flow are usually tapped from the main river for power production, then these systems are less vulnerable to climate change related water flow variations. This may be true for relatively large perennial rivers (which act as storage facilities in this case), but for relatively small rivers, SHP systems may be very vulnerable to water scarcity in the rivers due to absence of water storage systems.

Further, one of the climate change negative impacts is the occurrence of extreme weather events such as flooding and hailstorm. These may damage existing infrastructures such as the SHP systems. Again, scarcity of water resources as a result of climate change causes increased competition for the available water in the rivers (for power production and other uses) and may exacerbate the problem of waterrelated conflicts, since it will then be a scarce commodity; this may further negatively affect SHP generation. This, therefore, points out that SHP without storage system are more vulnerable to climate change and therefore issues of climate change must be considered during the planning and designing phase. This should, however, not to be looked at as a strong barrier towards implementation of SHP in the region, but should be taken as one of positive challenges to be solved so as to come up with a sustainable installation. Further, according to many experts, in Africa, climate change will exert pressure on the water sector affecting both its availability and quality [58]; hence, it is necessary to improve on the current knowledge on how climate change affects the small hydropower sector in the region so as to inform the designers and policy makers.

Climate change is defined by IPCC as a significant and lasting change in the statistical distribution of weather patterns over periods ranging from decades to millions of years. There are a lot of grey areas in the body of knowledge on how climate is changing within the region and even at country levels. Evidence that climate is changing in the region is based on anecdotal pieces of information on weather-related changes and events from countries and results from global circulation climatic model simulations. It is difficult to extract concrete conclusions about the influence of climate change at a country level from these global models since they are not able to fully mimic the dynamics of climate change at the country level. However, for planning purposes, the global analysis results on how climate change affects level of precipitation (thus runoff) and hence hydropower can provide some useful insights.

Globally, climate change is expected to increase precipitation and hence runoff as a result of snow melting due to the increased global average temperature [57], thus, a positive outlook for the hydropower sector. On a regional basis, for Africa, Arnell [61] conducted simulations using the 1996 IPCC's Special Report Emissions Scenarios for a river runoff projection up to the year 2050 using the HadCM3 climate model. The simulations indicated a significant decrease in runoff in the north and south of Africa, while the runoff in eastern Africa and parts of semiarid sub-Saharan Africa is projected to increase, indicating a positive future for hydropower sector in east Africa than other parts of the region. Again, simulation studies by Hamududu and Killingtveit [57] point out that there will be significant regional changes at worldwide level in river flow volumes and timing as a result of changes in precipitation and runoff. For the African Region, their simulations show a reduction in hydropower resource potential with the exception of East Africa, agreeing with Arnell [61] results. However, these simulations' results must be handled with care due to significant degrees of uncertainties coming from the generic assumptions when developing the scenarios.

Furthermore, climate change impacts on land use and environmental mismanagement in the catchment areas have rendered some of the identified potential sites not suitable for small hydropower generation due to buildup of silt and other debris, affecting the river basin and profile. Some of the installed SHP plants in the region are no longer working because of the problem of silt clogging the generating equipment. Therefore, catchment area management is also important to consider during the planning stage. Unsustainable harvesting of natural forest for energy and other purposes is one of the major environmental challenges in 
most of the sub-Saharan African countries' river catchment areas. This challenge is exacerbated by the fact that over $80 \%$ of the population in the region rely on biomass energy mostly in form of firewood and charcoal [62].

The other challenge concerning SHP technology in most of the SSA countries is lack of policy and regulatory framework to guide the development and implementation of the SHP systems. Insufficient regulatory framework leads to unhealthy situations in which, for example, SHP project developers often do not know which requirements apply and work in an unreliable grey area of regulation. This may discourage potential SHP developers from investing in the technology.

SHP is a cross-cutting technology; apart from engineering, it also involves agriculture, water resources management, and environmental management sectors as well as national power utilities, local authorities, and financing partners. It is thus important to include all these sectors during the project development, implementation, and operation stages to ensure sustainability of the technology. In case of rural electrification, neglecting of involvement of local authority and local communities can create obstacles in the operation of the SHP technology because the local communities may not cooperate effectively in water management upstream of the intake resulting into low power production.

\section{Conclusions}

The important findings from this paper are as follows: (i) there is an acute shortage of rural electricity supply in almost all of the sub-Saharan African countries and gridbased rural electricity supply is associated with a lot of challenges; (ii) small hydropower technology is one of the best suited technology for off-grid power supply but it is quite site-specific affecting both the design of the system and unit power investment cost; therefore, it needs dedicated planning and system design stages; (iii) sub-Saharan African region has a lot of identified small hydropotential sites and are recorded in some of the countries' small hydropower inventories, but most of these sites have not undergone full feasibility studies both technical and economic; therefore, these inventories are inadequate in providing required design data and other useful information to potential developers; (iv) basing on the reported estimates of SHP potential data available in many countries of the region, it is reasonable to qualitatively state that the region is well endowed with SHP potential; (v) despite having scattered information on country level SHP installation levels, this paper how that the region has very low levels of SHP installation (in relation to potential estimates available) and that most of them are initiated by international development agencies - it is in Rwanda, Kenya and Uganda that private developers have started participating in SHP power generation, on independent power producer arrangement; therefore, case studies on such "success stories" may be conducted to inform formulation of upcoming similar projects in other countries in the region; (vi) there are many challenges hampering development and implementation of SHP projects in the region, technological challenges including lack of local human capacity to plan, design, manufacture, install, and operate SHP projects are quite pronounced in many countries in the region; the presence of a regional centre of excellence in SHP technology development in Abija, Nigeria plus outputs of SHP regional projects on capacity building as reviewed in the paper should be utilised and possibly scaled up at country levels, possibly utilising the already existing national research and technology development centres. Technological innovations such as concerning the development of efficient SHP components (for example turbines) for the rural SSA scenario should also be encouraged in the region.

Lack of funds to finance SHP projects has been mentioned as one of the challenges facing the SHP development in SSA. As discussed in the paper, most of the SHP projects rely on funding from development partners and central governments, and, in most cases, the funding is just able to finance a portion of the available hydropower potential in the country. To become less dependent on donors and public (central government) funding, strategies must therefore be put in place on how to attract other sources of financing such as from the private money lending institutions (like commercial banks).

The SHP is traditionally designed for a particular site because of the technology being site specific, as discussed in the paper. Considering the diverse range of sites in terms of levels of heads and flow rates, there is need for a design of modularized and standardized SHP system to be applied to a range of potential sites. This will help to effectively exploit SHP resources available on the site as well as to help in management of the SHP technology in terms of availability of spare parts since the spares will not only be specific to the type of plant installed on a particular site. When conducting feasibility study, apart from quantifying the firm power potential available at the site, it is also important to select the suitable installation technology that matches the modular system on the site (for example, selecting the range of modular turbines match the site power characteristics).

Despite the challenges, this paper shows that small hydropower technology has the potential for power generation in sub-Saharan Africa especially for rural power supply. The challenges discussed in the paper should be looked at as negative stumbling blocks, but rather as areas to work on during planning stage so as to improve on the sustainable technology development and implementation in the region.

\section{References}

[1] S. Singal, "Planning and implementation of Small Hydropower (SHP) projects," Hydro Nepal, no. 5, 2009, http://www .mtnforum.org/sites/default/files/pub/6220.pdf.

[2] A. Eberhard, V. Foster, C. Briceño-Garmendia, F. Ouedraogo, D. Camos, and M. Shkaratan, "Underpowered: the state of the power sector in sub-Saharan Africa," Background Paper 6, Africa Infrastructure Country Diagnostic. Published by The World Bank, Washington, DC, USA, 2008, http://www.infrastructureafrica.org/system/files/BP6_Power_sect_annex1_0 .pdf. 
[3] US Energy Information Administration, "International energy statistics-electricity in SubSaharan Africa (2000-2009)," Published by the US Energy Information Administration, 2012, http://www.eia.gov/cfapps/ipdbproject/iedindex3.cfm? tid=2\&pid=28\&aid=12\&cid=regions\&syid=2000\&eyid $=2009$ \&unit=BKWH\#.

[4] M. Duarte, S. Nagarajan, and Z. Brixiova, "Financing of sustainable energy solutions," AfBD Committee of Ten Policy Brief, Published by AfBD-African Development Bank, Ivory Cost, 2010, http://www.afdb.org/fileadmin/uploads/afdb/Documents/Publications/C-10\%20Note\%203\%20English\%20 (final)_for\%20posting.pdf.

[5] REN21-Renewable Energy Policy Network for the 21st Century, "Renewables 2011 global status report," Published by REN 21, Paris, France, 2011, http://www.ren21.net/Portals/ 97/documents/GSR/REN21_GSR2011.pdf.

[6] IEA-International Energy Agency, "Access to electricity," Report, Published by the International Energy Agency, Paris, France, 2012, http://www.iea.org/weo/electricity.asp.

[7] O. Rosnes and H. Vennemo, "Powering up: costing power infrastructure spending needs in Sub-Saharan Africa," Africa Infrastructure Country Diagnostic (AICD) Background Paper Number 5, World Bank, Washington, DC, USA, 2008.

[8] A. Eberhard, O. Rosnes, M. Shkaratan, and H. Vennemo, "Africa's power infrastructure: investment, integration, efficiency," World Bank Report. Washington, DC, USA, 2011, http://www.ppiaf.org/sites/ppiaf.org/files/publication/AfricasPower-Infrastructure-2011.pdf.

[9] M. Vagliasindi and J. Nellis, "Evaluating Africa's experience with institutional reform for the infrastructure sectors," Africa Infrastructure Country Diagnostic (AICD) Working Paper Number 22, World Bank, Washington, DC, USA, 2010.

[10] M. Krause and S. Nordstrom, Solar Photovoltaics in Africa. Experiences with financing and delivery models, UNDP, New York, NY, USA, 2004.

[11] L. Mabuza, A. Brent, and M. Mapako, "The transfer of energy technologies in a developing country context-towards improved practice from past successes and failures," World Academy of Science, Engineering and Technology Journal, vol. 28, pp. 237-241, 2007, http://www.waset.org/journals/waset/ v28/v28-43.pdf.

[12] ESHA-European Small Hydropower Association, Guide on How to Develop a Small hydropower Plant, Chapter 1, Introduction, ESHA, Brussels, Belgium, 2004, http://www.esha.be/ fileadmin/esha_files/documents/publications/GUIDES/GUIDE_SHP/GUIDE_SHP_EN.pdf.

[13] Natural Resources Canada, "Micro hydropower systems: a buyers guide," Published by Natural Resources Canada, Cat. No. M144-29/2004E, 2004, http://www.builditsolar.com/Projects/Hydro/CanadaMicroHydroGuide.pdf.

[14] D. Singh Asian and Pacific Centre for Transfer of Technology under United Nations Economic and Social Commission for Asia and Pacific (ESCAP), 2009, http://recap.apctt.org/Docs/ MicroHydro.pdf.

[15] O. Paish, "Micro-hydropower: status and prospects," Journal of Power and Energy, vol. 216, no. 1, pp. 31-40, 2002.

[16] S. Singal, "Planning and implementation of Small Hydropower (SHP) projects," Hydro Nepal, No. 5, July, 2009, http:// www.mtnforum.org/sites/default/files/pub/6220.pdf.

[17] A. Ghosh, S. Majumdar, and A. Kaur, "Steady growth in small hydro power; however significant, challenges remain," ICRA (Investment Information and Credit Rating Agency of India Limited) Rating Feature, May 2012, http://www.icra.in/ Files/ticker/SHP\%20note-.pdf.
[18] W. Klunne, "Microhydro power in Rural Africa," Energy4 Africa Publications, Challenge, 8 Pages, 2011, http://energy4africa.net/klunne/publications/challenge_Spring2011_hydropower.pdf.

[19] P. Subbarao, "Hydrology for design of hydro power plants," Lecture Notes, Indian Institute of Technology, Department of Mechanical Engineering, 2012, http://web.iitd.ac.in/ pmvs/ mel346/mel346-14.ppt.

[20] R. Uhunmwangho and E. Okedu, "Small hydropower for sustainable development," The Pacific Journal of Science and Technology, vol. 10, no. 2, pp. 535-543, 2009.

[21] IPCC-Intergovernmental Panel on Climate Change, Renewable Energy Sources and Climate Change Mitigation: Special Report of the Intergovernmental Panel on Climate ChangeChapter 5, Hydropower, Cambridge University Press, New York, NY, USA, 2007.

[22] V. Schnitzer, "Micro hydropower scout guide: a field workers manual," Published by GTZ, under Access to Modern Energy-Ethiopia Project, 2009.

[23] S. Williamson, B. Stark, and J. Booker, "Low head pico hydro turbine selection using a multi-criteria analysis," vol. 6 of Hydropower Applications, pp. 1377-1395, Proceedings of World Renewable Energy Congress, Linköping, Sweden, May 2011.

[24] O. Paish, "Small hydro power: technology and current status," Renewable and Sustainable Energy Reviews, vol. 6, no. 6, pp. 537-556, 2002.

[25] S. Khennas and S. Barnett, "Best Practices for sustainable development of micro-hydro power in developing countries," Final Synthesis Report, Intermediate Technology Development Group Limited, England, UK, 2000, Submitted to DfID and World Bank.

[26] K. Kabaka and F. Gwang'ombe, "Challenges in small hydropower development in Tanzania: rural electrification perspective," in Proceedings of the International Conference on Small Hydropower-Hydro Sri Lanka Conference, October 2007, http://ahec.org.in/links/International\%20conference $\%$ 20on\%20SHP\%20Kandy\%20Srilanka\%20All\%20Details/Papers/Policy.

[27] JICA-Japan International Cooperation Agency, "Master plan on rural electrification in Malawi. Full technical report," Published by JICA, Report Submitted to Department of Energy Affairs in the Ministry of Natural Resources and Environmental Affairs, Government of Malawi, 2003.

[28] S. Denadde and A. Ahenkorah, "Mini hydro power in Ghana: prospects and challenges," Tech. Rep., Energy Foundation of Ghana, 2002, http://www.ghanaef.org/publications/documents/Mini\%20Hydro\%20Power\%20in\%20Ghana $\% 20-\% 20$ REPORT.pdf.

[29] GOM-Government of Malawi, National Energy Plan. Department of Energy Affairs, Government Printing Press, Zomba, Malawi, 1997.

[30] R. van der Plas and A. Kyezira, Uganda's Small-Hydro Energy Market, Deutsche Gesellschaft für Technische Zusammenarbeit (GTZ) GmbH, Berlin, Germany, 2009.

[31] M. Hankins, Renewable Energy Plan for Mozambique, Justiça Ambiental, Maputo, Mozambique, 2009, http://www.internationalrivers.org/files/Clean\%20Energy\%20for\%20MZ\%2030_ 9_09.pdf.

[32] RURA—Rwanda Utilities Regulatory Agency, "Rwanda power supply review," RURA Report, 2009, http://www.rura.govrw/ docs/RURA/\%5BRwanda_power_situation\%5D.pdf.

[33] GOG-Government of Ghana, Ghana National Energy Policy, Ministry of Energy, Accra, Ghana, 2010, http://ghanaoilwatch .org/images/laws/national_energy_policy.pdf. 
[34] W. Kipyego, "Small hydropower development in Kenya," in Proceedings of the Small Hydropower Technology for Developing Countries Conference, Hangzhou, China, June 2011, http:// nrec.mn/data/uploads/Nom\%20setguul\%20xicheel/Water/ badrakh\%20china/Kenya.pdf.

[35] WAEA-Ministerial Conference on Water for Agriculture and Energy, "Hydropower resource assessment of Africa," in Proceedings of the Ministerial Conference on Water for Agriculture and Energy (WAEA) in Africa: The Challenges of Climate Change, Sirte, Libya, December 2008, http://www.sirtewaterandenergy.org/docs/2009/E(Sirte_2008_INF_4).pdf.

[36] C. Kaunda, "Energy situation, potential and application status of small scale hydropower systems in Malawi," unpublished paper, The Polytechnic, University of Malawi.

[37] F. Mtalo, "Small scale hydropower for rural development: country report for Tanzania," Hydropower Research Cluster Report for the Nile Basin Capacity Building Network (NBCBN), Published by NBCBN, Cairo, Egypt, 2005, http:// www.nbcbn.com/Project_Documents/Progress_Reports/HpG1.pdf.

[38] P. Mbuthi, "Power sector reforms and regulatory framework, prospects and challenges of small hydropower development in Kenya," in Proceedings of the UNEP/GEF and East African Tea Trade Association (EATTA) Conference, Nairobi, Kenya.

[39] GOR-Government of Rwanda, Rwanda State of Environment and Outlook Report, Government of Rwanda, 2010, http://www.rema.gov.rw/soe/full.pdf.

[40] T. Meir and G. Fischer, Assessment of the Pico and Micro Hydropower Market in Rwanda, Global Village Energy Partnership International, Nairobi, Kenya, 2011, http://www.gvepinternational.org/sites/default/files/pico-hydro_market_in_ rwanda.pdf.

[41] S. Denadde and A. Ahenkorah, "Mini hydro power in Ghana: prospects and challenges," Tech. Rep., Energy Foundation of Ghana, 2002, http://www.ghanaef.org/publications/documents/Mini\%20Hydro\%20Power\%20in\%20Ghana\%20-\%20REPORT.pdf.

[42] GOM-Government of Malawi, Malawi State of Environment and Outlook Report: Chapter 10-Atmosphere and Climate, Malawi Environmental Affairs Department, Nairobi, Kenya, 2010.

[43] A. Esan, "UNIDO regional centre and small hydro power development in Africa-Abuja, Nigeria," in Proceedings of the Instruments and Potential for the Use of Renewable Energies for Regional Development Conference, International Centre for Science and Technology and UNIDO (United Nations Industrial Development Organisation), Trieste, Italy, May 2011, http://www.ics.trieste.it/media/719540/29.\%20Esan.pdf.

[44] UNIDO-United Nations Industrial Organisation, "UNIDO projects for the promotion of small hydro power for productive use: independent thematic review," Tech. Rep., UNIDO, Vienna, Austria, 2010, http://www.unido.org/fileadmin/ user_media/About_UNIDO/Evaluation/Project_reports/ebook_small-hydro.PDF.

[45] Energy for Life, "Pico hydro system local made in Tanzania," Project Report, Oikos East Africa, 2012, http://www.energieist-entwicklung.de/download/18_TZ_Oikos-Hydro.pdf.

[46] GEF-Global Environmental Facility, "Greening tea industry in East Africa project approval document," 2012, http://www .thegef.org/gef/sites/thegef.org/files/repository/Regional\%20\%20Greening\%20Tea\%20Industry\%20in\%20EastAfrica.pdf.

[47] W. Klunne, "Sustainable implementation of microhydro to eradicate poverty in Africa," in Proceedings of the World Energy Congress Conference, Montreal, Canada, May 2010, http://www.worldenergy.org/documents/congresspapers/330 .pdf.

[48] IED - Innovation Energie Development, "Poverty alleviation through cleaner energy from agro-industrial in Africa (PACEAA), Lujeri tea factory rural electrification plan: Mulanje Malawi," IED Report, 2009, http://www.paceaa.org/ Electrification\%20Plans/Rural\%20Electrification\%20Plan\% 20report\%20Lujeri_V5.pdf.

[49] UNEP-United Nations Environment Program, "Mid-term evaluation of the UNEP/GEF project GF/4010-05-02 (4870): Greening the Tea Industry in East Africa (GTIEA)," Prepared by U. Meier, and Z. Ogutu, UNEP Consultants, 2010, http:// www.unep.org/eou/Portals/52/Reports/GTIEA_MTE_Final .pdf.

[50] GEF-Global Environmental Facility, "UNDP-GEF regional microhydropower project framework document," 2012, http: //www.esmap.org/esmap/sites/esmap.org/files/ProgramFrame workDocument_GEF_Strategic_Program_West_Africa .pdf.

[51] S. Chandirekera and M. Makuyana, "Financial and ownership models for micro-hydro schemes in Southern Africa," Boiling Point, no. 58, 2010.

[52] Practical Action/e-mindset, "Catalyzing modern energy service delivery to marginal communities in Southern Africa," in Proceedings of the Annual Review and Planning Workshop, Blantyre, Malawi, February 2008, http://www.hedon.info/ docs/E-MINDSET-AnnualReviewReport-MalawiFebruary 2008.pdf.

[53] M. Gaul, F. Kölling, and M. Schröder, "Policy and regulatory framework conditions for small hydro power in Sub-Saharan Africa," Discussion Paper, 2012, http://www.gtz.de/de/dokumente/gtz2010-en-HERA-EUEI-PDF-framework-conditionshydropower.pdf.

[54] F. Mtalo, R. Wakati, A. Towo, S. Makanu, O. Munanyeza, and B. Abate, Design and Fabrication of Crossflow Turbine, Nile Basin Capacity Building Network, Cairo, Egypt, 2010, http:// www.nbcbn.com/Project_Documents/Progress_Reports_2010/ Local_Actions/Tanzania-local-2010.pdf?phpMyAdmin=1e796 e9e294108ca4f0d0ff59.

[55] J. Susanto and M. Smits, "Towards a locally adapted rural electrification assessment framework: a case study of the Lao PDR," in Proceedings of the International Conference for a Sustainable Greater Mekong Subregion, Bangkok, Thailand, August 2010, http://www.sunlabob.com/data/documents/energy_issues/O-10-08-Rural_Electrification_Assessment_Frame work.pdf.

[56] A. Eberhard, V. Foster, C. Briceño-Garmendia, F. Ouedraogo, D. Camos, and M. Shkaratan, "Underpowered: the state of the power sector in Sub-Saharan Africa," Africa Infrastructure Country Diagnostic Background Paper Number 6, The World Bank, 2008, http://www.infrastructureafrica.org/ system/files/BP6_Power_sector_maintxt.pdf.

[57] B. Hamududu and A. Killingtveit, "Assessing climate change impacts on global hydropower," Journal of Energies, vol. 5, no. 2, pp. 305-322, 2012.

[58] IPCC-Intergovernmental Panel on Climate Change, "Climate change and water," IPCC Technical Paper VI, IPCC Secretariat, Geneva, Switzerland, 2008.

[59] J. Ebinger and W. Vergara, "Climate impacts on energy systems: key issues for energy sector adaptation," Energy Sector Management Assistant Program (ESMAP) of the World Bank, 2011.

[60] W. Klunne, "Microhydropower in rural Africa," Challenge, no. 6, Spring 2011, http://energy4africa.net/klunne/publications/ challenge_Spring2011_hydropower.pdf. 
[61] N. W. Arnell, "Climate change and global water resources: SRES emissions and socio-economic scenarios," Global Environmental Change, vol. 14, no. 1, pp. 31-52, 2004.

[62] EuropeAid, ACP-EU Energy Facility Biomass Energy Position Paper, European Commission, Development and Cooperation-EuropeAid, Brussels, Belgium, 2011, http://ec.europa .eu/europeaid/where/acp/regional-cooperation/energy/documents/biomass_position_paper_en.pdf. 

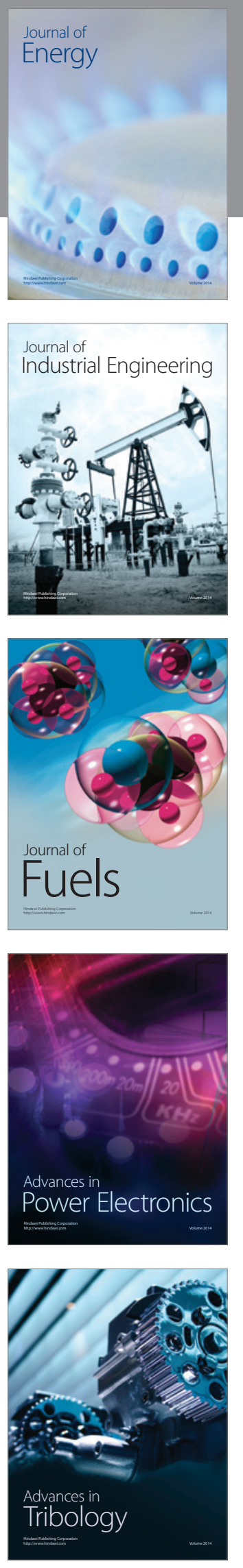
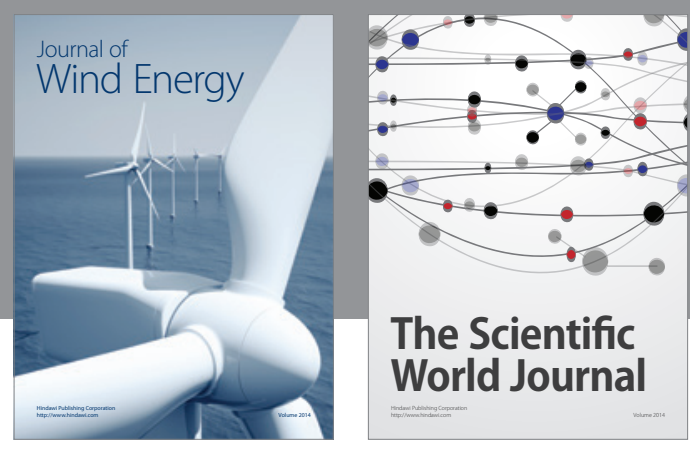

The Scientific World Journal

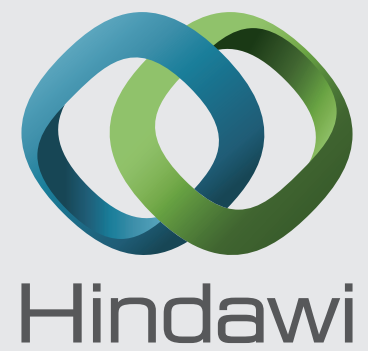

Submit your manuscripts at http://www.hindawi.com
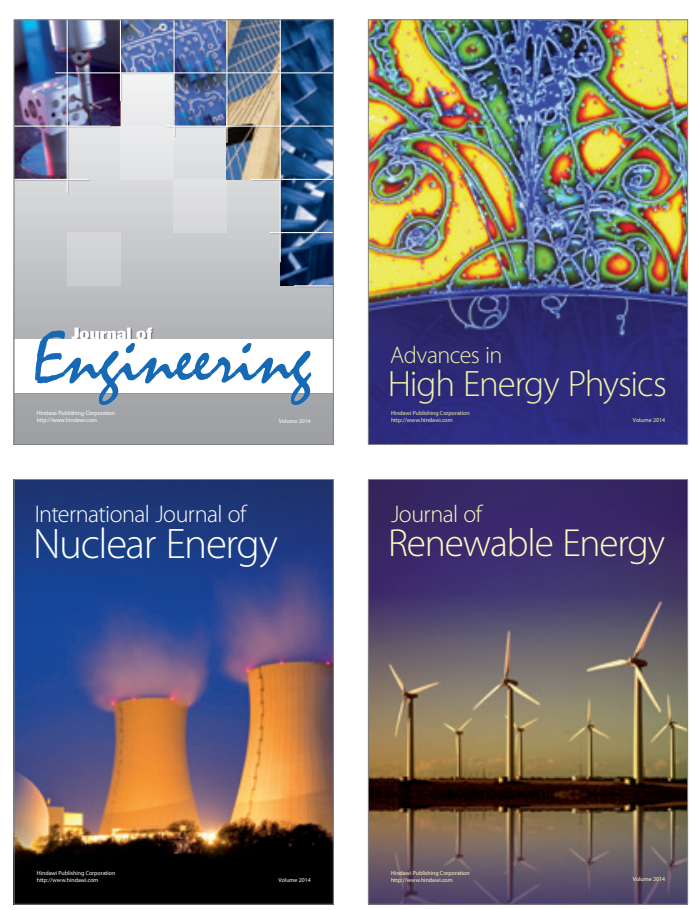

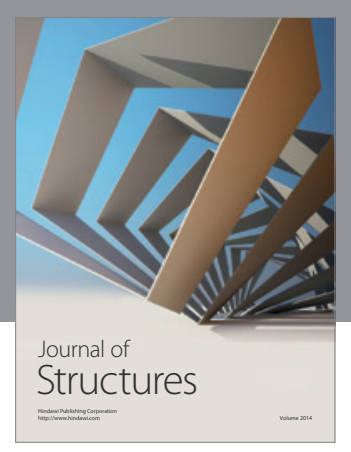

Rotating
Mechinery
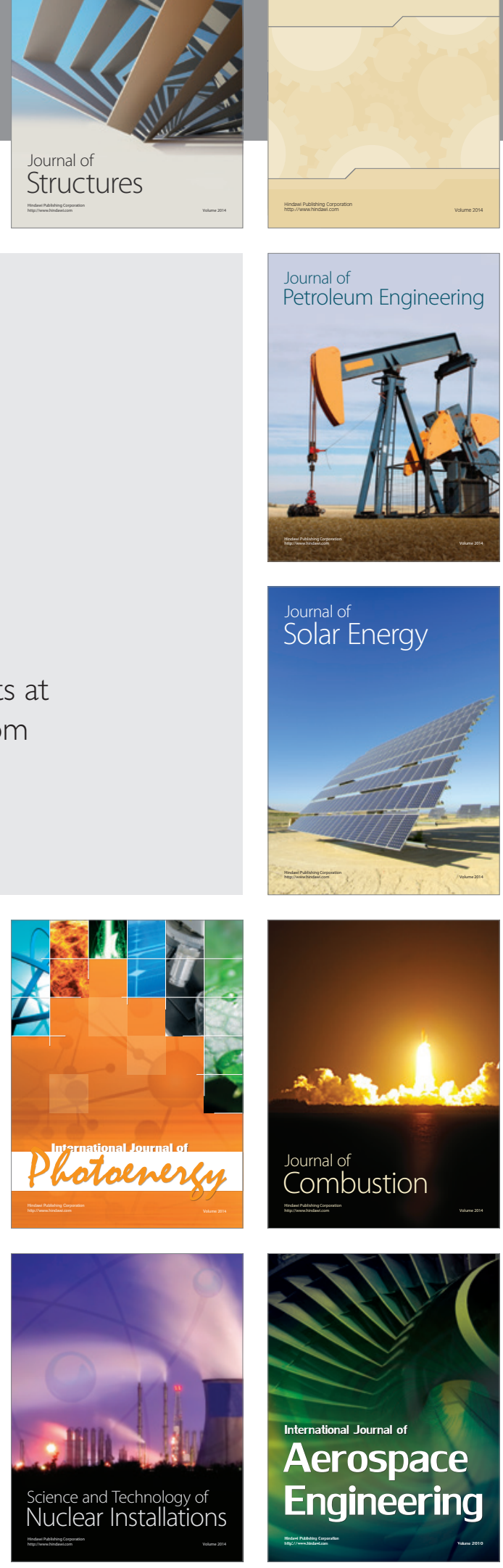